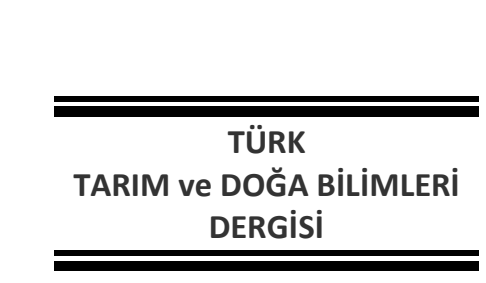



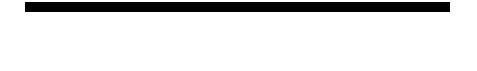

\title{
Termal Analiz ve Diferansiyel Termal Analiz Yöntemleri Karşılaştırılarak Asma Kış Gözlerine Ait Ölüm Noktalarının Tespiti
}

\author{
Özkan KAYA ${ }^{1 *}$, Cafer KÖSE $^{2}$ \\ ${ }^{1}$ Erzincan Bahçe Kültürleri Araştırma Enstitüsü, 24060 Erzincan, Türkiye \\ ${ }^{2}$ Atatürk Üniversitesi, Ziraat Fakültesi, Bahçe Bitkileri Bölümü, 25240 Erzurum, Türkiye \\ *Sorumlu yazar: kayaozkan25@hotmail.com
}

Geliş Tarihi: 13.09.2018

Düzeltme Geliş Tarihi: 04.01.2019

Kabul Tarihi: 14.01.2019

\begin{abstract}
Özet
Bu araştırmada, yapay don şartları altında Termal Analiz (TA) ve Diferansiyel Termal Analiz Yöntemleri (DTA) ilk kez birlikte kullanıımış ve bu iki test metodunun birbiriyle karşılaştırılması yapılarak asma kı̧̧ gözlerinin

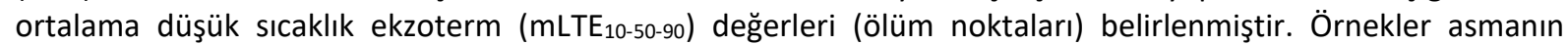
zorunlu dinlenme döneminde olduğu altı farklı dönemde alınarak teste tabi tutulmuştur. Bulgularımızda, kış gözlerinden elde edilen $\mathrm{mLTE}_{10-50-90}$ sıcaklık değerleri, TA yöntemi kullanıldığında -7.66 ile $-11.72^{\circ} \mathrm{C}$, DTA yöntemi kullanıldığında ise -9.20 ile $-22.84^{\circ} \mathrm{C}$ arasında tespit edilmiştir. Genel olarak iki metoda göre yapılan analiz sonuçlarında gözlerinin don toleransı havaların soğumasıyla beraber artmış ve baharda havaların ısınması ile yeniden azalmıştır. Sonuçlara göre DTA yöntemi ile belirlenen mLTE sıcaklıkları TA yöntemi ile karşılaştıııııı̆ında 1.24 ile $12.80^{\circ} \mathrm{C}$ arasında daha düşük sıcaklıklarda görülmüştür. Öte yandan TA yönteminde tomurcuklar içerisine yerleştirilen termokuplların gözlerde deformasyon oluşturarak mLTE değerlerinin daha yüksek sıcaklıklarda meydana gelmesine neden olduğu belirlenmiştir. Bu yüzden sonraki araştırmalarda farklı asma çeşit ve türlerine ait kış gözlerinin don toleransı tahminlerinde DTA yönteminin kullanılması ile daha gerçekçi verilerin elde edilebileceği kanaatine varılmıştır.
\end{abstract}

Anahtar kelimeler: Don toleransı, asma, ekzoterm, aklimasyon, deklimasyon.

\section{Detection of Death Point in Grapevine Dormant Buds by Comparing Thermal Analysis and Differential Thermal Analysis Methods}

\begin{abstract}
In this study, Thermal analysis (TA) and Differential Thermal analysis (DTA) were used, together for the first time under artificial frost conditions in the lab. The mean low temperature exotherm values ( $\mathrm{mLTE}_{10-50-90)}$ of grapevine dormant buds were determined comparing TA and DTA methods. Samples were taken at six different times during dormant period. In our results, $m L T E_{10-50-90}$ values were from -7.66 to $-11.72^{\circ} \mathrm{C}$ by using $T A$ methods while $\mathrm{mLTE}_{10-50-90}$ values changed from -9.20 to $-22.84^{\circ} \mathrm{C}$ using DTA methods. In both TA and DTA analysis results, freezing tolerance of the dormant buds increased as the temperature decreased and decreased as the temperature increased in spring, generally. In conclusion, when DTA methods were compared to TA methods in terms of $\mathrm{mLTE}$ temperatures, $\mathrm{mLTE}$ temperatures were determined by DTA method were 1.24 to $12.80^{\circ} \mathrm{C}$ lower than TA method. On the other hand, thermocouples were located in the dormant buds caused deformation in the bud tissues and thus this deformation caused by the occurrence of the LLTE $_{10-50-90}$ values at higher temperatures. Therefore, it is concluded that more accurate data can be obtained by using the DTA method in predicting frost tolerance of dormant buds different grapevine cultivars and species in future studies.
\end{abstract}

Key words: Frost tolerant, grapevine, exotherm, acclimation, de-acclimation. 


\section{Giriş}

Düşük sıcaklık stresi pek çok bitki türünde olduğu gibi, meyve türleri içerisinde önemli bir yere sahip olan asma bitkisinin de dünya üzerinde yayılmasında sınırlayıcı iklim faktörlerinin başında gelmektedir (Kaya ve Köse, 2017). Genel olarak düşük sıcaklık stresi sonbahar, kış ve ilkbahar aylarında meydana gelmekte ve dünyada üzüm üretiminin yapıldığı pek çok bölgede zaman zaman telafisi olmayan önemli ekonomik kayıplara neden olmaktadır (Buztepe ve ark., 2017). Ayrıca bazı yıllar şiddetli ekstrem düşük sıcaklıklar bağ alanlarında omcaların tamamına yakınının ölümüne neden olmakta ve bu durum hem üretici hem de üretime dayalı kuruluşlar için büyük problemlere yol açmaktadır (Grant ve Dami, 2015). Bu tarz problemler genel olarak dünya üzüm üretiminin \%90'ından fazlasını kapsayan $V$. vinifera $L$. çeşitlerinin tolerans sınırı olan $-25^{\circ} \mathrm{C}^{\prime}$ nin aşıldığı kış sıcaklıklarında meydana gelmektedir (Fennell, 2004; Kalkan ve ark., 2017; Köse ve Kaya, 2017; Kaya ve Köse, 2018). Öte yandan V. vinifera L. türü içerisine giren asma çeşitlerinin düşük sıcaklıklara tolerans dereceleri dönem ve çeşitlere göre farklııı göstermektedir (Köse ve Güleryüz, 2009). Zira omcanın fizyolojik olarak aklimasyon, dayanıklılık ve deaklimasyon dönemleri içerisinde düşük sıcaklıklara gösterdiği tolerans derecesi farklıdır (Rende ve ark., 2018). Özellikle bu dönemlerde pek çok biyokimyasal madde ve hücre suyunun don toleransı üzerine önemli etkisi vardır (Zhang ve ark., 2012). Nitekim dinlenmeye giriş ile hücre suyu yavaş yavaş azalırken, derin dinlenmede minumun düzeye gerilediği ve deaklimasyon ile tekrardan yükselmeye başladığı bilinmektedir (Keller, 2015; Kaya ve Köse, 2018). Ayrıca bu süreçte biyokimyasal maddelerin birbiri ile dönüşümlerinde de bir takım etkileşimler meydana gelmektedir (Zhang ve ark., 2012; Rende ve ark., 2018). Bu dönemlerde meydana gelen değişimler ve bu değişimlerin don toleransı üzerine olan etkileri farklı ölçüm tekniklerinin kullanılması ile araştırmacılar tarafından test edilmektedir.

Yaprağını döken ve süper soğuma özelliği gösteren pek çok meyve türünde olduğu gibi asma doku ve organlarının don toleransının belirlenmesinde Termal Analiz (TA) ve Diferansiyel Termal Analiz Yöntemleri (DTA) yaygın olarak kullanılmaktadır (Pierquet ve ark., 1977; Andrews ve ark., 1984; Mills ve ark., 2006; Kaya ve Köse, 2017; Buztepe ve ark., 2017; Rende ve ark., 2018; Kaya ve ark., 2018; Kaya ve Köse, 2018). Asma organlarının ekzoterm sıcaklıkları TA yönteminde tek bir termokupl sensörünün dokuya yerleştirilmesiyle (Quamme ve ark., 1975; Kaya ve Köse, 2018), DTA yönteminde ise organ parçalarının termoelektrik modüller üzerine konulması ile belirlenmektedir (Mills ve ark., 2006; Kaya ve ark.,
2018). Laboratuvar temelli yapay don testleri altında dondurulan dokularda süper soğuma sınırının aşılmasıyla hücreler arası ve hücreler içinde ISI yükselmesi meydana gelmektedir (Andrews ve ark., 1984). Ortaya çıkan bu gizli ısı hem TA hem de DTA yöntemleri yardımı ile kaydedilmekte ve dokuların ölümü ile sonuçlanan hücre içi donma, düşük sıcaklık ekzotermi olarak ifade edilmektedir (Grant ve Dami, 2015; Rende ve ark., 2018). Ancak bu iki yöntem ile doku ve organların eksoterm sıcaklıkları belirleniyor olsa da TA yönteminin eksik yanlarının olduğu zaman içerisinde bazı araştırmacılar tarafından ortaya konulmuş (Quamme, 1978; Proebsting ve Sakai, 1979; George ve ark., 1982) fakat TA yönteminin DTA yöntemi ile karşılaştırılması birlikte değerlendirilmemiştir. Bu yüzden mevcut çalışmada asma kış gözlerinin ekzoterm sıcaklıkları farklı örnekleme dönemlerinde TA ve DTA yöntemleri ile test edilmiş ve elde edilen ölüm sıcaklıkları yardımı ile bu iki metodun birbirine karşı üstün ve zayıf yanları ortaya konulmuştur.

\section{Materyal ve Yöntem Bitki materyali}

$\mathrm{Bu}$ çalışma 2015-2016 yılları arasında yürütülmüştür. Araştırmada, TA ve DTA yöntemleri için kullanılan asma kış gözleri, Erzincan İli, Üzümlü İlçesi sınırları içerisinde bulunan Karaerik üzüm çeşidinden oluşan Baran sisteminde terbiye edilmiş 25 yaşındaki bir bağdan alınmıştır. Her bir örnekleme tarihinde ( 30 Kasım 2015, 20 Aralık 2015, 10 Ocak 2016, 20 Şubat 2016 ve 10 Mart 2016) 70-80 adet 6-7 gözlü bir yaşlı dal alınmıştır. Bağ şartlarında alınan örnekler polietilen torbalara konularak mümkün olduğu en kısa sürede laboratuvara getirilmiş ve analizlerde çeşit için verimli kabul edilen ilk 4 kış gözü kullanılmıştır.

\section{Kış gözlerinde termal analiz yöntemi}

Termal analiz testleri için, bir yaşlı sürgünlere ait boğumlardan $5-7 \mathrm{~cm}$ boyunda çelikler kesilmiş ve bu çeliklerdeki kış gözler kullanılmıştır. Numuneler tekerrürlü ve her tekerrürde 4 çelik olacak şekilde hazırlanmıştır. Çelikler test için laboratuvar şartlarında hazırlanmış ve örnekler 3 tekerrür halinde gruplara ayrılmıştır. Çalışmada her bir örnekleme dönemi için toplam 54 göz test edilmiştir. Her bir grup için kullanılan tek gözlü çeliklere 36 gauge kalınlığındaki, T tipi termokupllar yerleştirilmiştir (Şekil 1a). Araştırmada termokuplların primer tomurcuklara yerleştirilmesinde titizlik gösterilmiştir. Termokupl yerleştirilen çeliklerde ekzoterm sıcaklıkların belirlenme şansını artırmak için göz ve termokupl üzeri termal özelliği olmayan silikonla kaplanmıştır (Şekil 1b). Örnekler daha sonra sıcaklık dalgalanmalarından korunmak amacıyla alüminyum 
folyo ile sarılarak sıcaklığı kontrol edilebilir kabine yerleştirilmiştir (Şekil 1c). Kabin sıcaklığı $4^{\circ} C^{\prime} y e$ ayarlanmış ve kabin içerisinde 1 saat bu sıcaklıkta tutulan örnekler sıcaklık düşüş adımları saatte $4^{\circ} \mathrm{C}$ olacak şekilde $-40^{\circ} \mathrm{C}^{\prime}$ ye kadar soğutulmuştur (Rende ve ark., 2018). Sıcaklık düşüş sürecinde primer tomurcuklardan elde edilen eksoterm sıcaklıkları datalogger ile 3sn aralıklarla bilgisayara kaydedilmiştir (Şekil 1d). Verilerin işlenmesi ile kış tomurcuklarının \%10, \%50 ve \%90 ölümünü temsil eden düşük sıcaklık ekzoterm (mLTE 10-50-90) sıcaklıkları tespit edilmiştir.

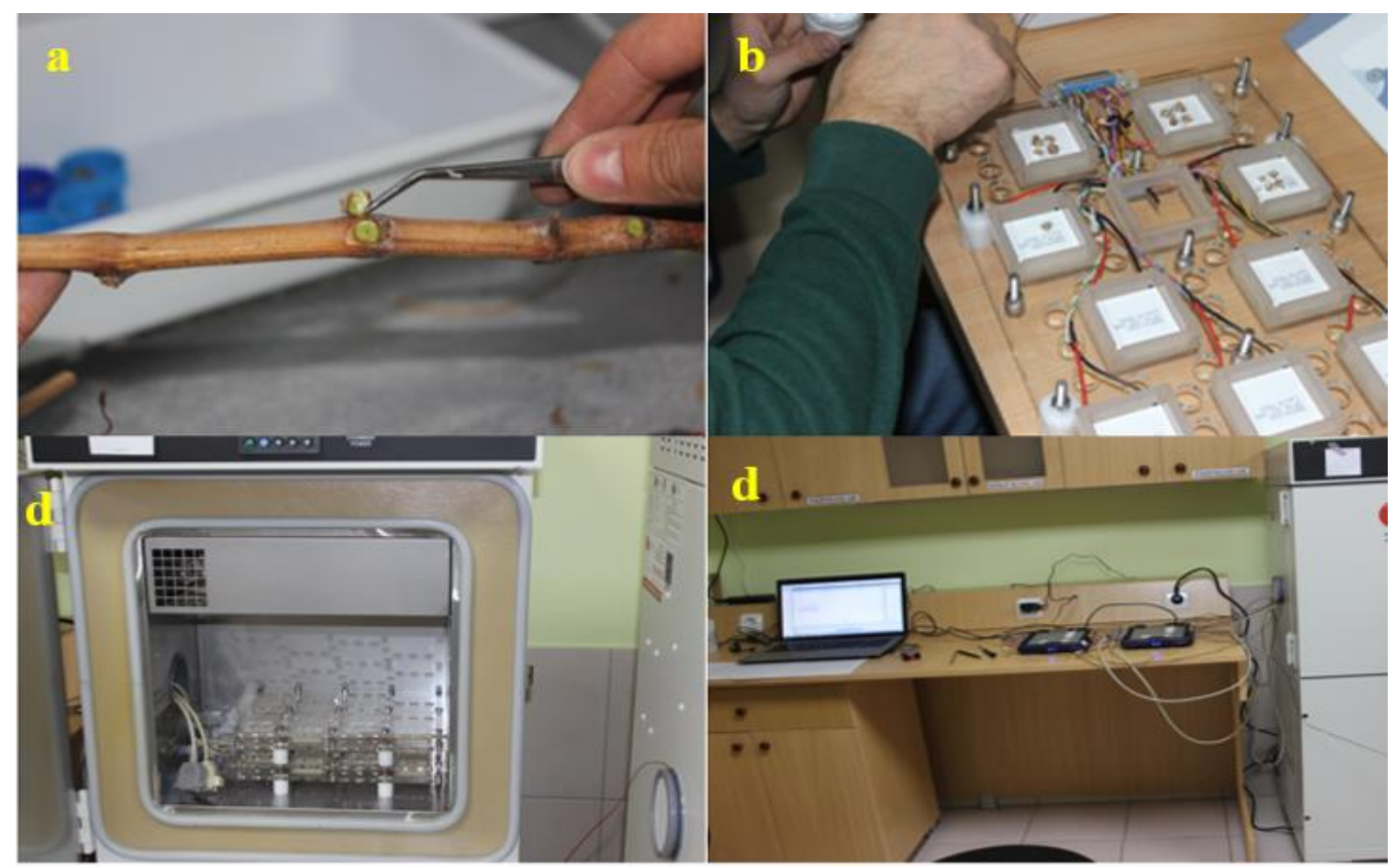

Şekil 1. DTA yönteminin ile kış gözlerinde mLTE değerlerinin belirlenmesi; a. tomurcuk yatağının altında 1-2mm odun dokusunun kesilmesi b. tomurcukların termoelektirik modüllere yerleştirilmesi, c. tomurcukların sıcaklık kontrollü kabine konulması, d. sıcaklık kontrollü kabine konulan tomurcuklarda veri kayıtlarının alınması

\section{Kış gözlerinde diferansiyel termal analiz yöntemi}

Her bir grup için DTA test örnekleri, 5-6 gözlü olarak alınan çeliklerin Karaerik üzüm çeşidi için verimli kabul edilen ilk 4 gözünden hazırlanmıştır. Test edilecek gözler üzerinde bırakılacak odun dokusu büyüklüğünün LTE sıcaklıkları üzerinde etkili olmasından dolayı (Andrews ve ark., 1984; Mills ve ark., 2006) çeliklerin ilk 4 gözünden hazırlanacak DTA test örneklerinde $1-2 \mathrm{~mm}$ boğum parçası bırakılmasına özen gösterilmiştir (Şekil 2a). Hazırlanan test örnekleri, 9'ar termoelektrik modül (TEM)'den oluşan tablalara, her TEM için 4'er göz olacak şekilde yerleştirilmiştir (Şekil 2b). DTA testinde bir tekerrürde 6 TEM olmak üzere, 3 tekerrür halinde her bir örnekleme dönemi için toplam 72 göz test edilmiştir. DTA testi için kontrollü kabinin sıcaklığı $4^{\circ} C^{\prime} y e$ ayarlanmış ve kabin içerisinde 1 saat bu sıcaklıkta tutulan örnekler, sıcaklık düşüş adımları saatte $4^{\circ} \mathrm{C}$ olacak şekilde $40^{\circ} \mathrm{C}^{\prime}$ ye kadar (Şekil 2c) soğutulmuştur (Kaya ve ark., 2018). Ardından kış gözlerinden elde edilen ekzoterm sıcaklıkları datalogger ile anlık olarak bilgisayara kaydedilmiş (Şekil 1d) ve verilerin kaydedilmesi ile kış tomurcuklarının \%10, \%50 ve \%90 ölümünü temsil eden düşük sıcaklık ekzoterm (mLTE ${ }_{10-50-90)}$ değerleri tespit edilmiştir.

\section{istatistik analiz}

Verilerin değerlendirilmesinde JUMP 7.0.1 (version. 7.0, SAS Institute Inc., Cary, NC) istatistik programından yararlanılarak hem TA hem de DTA analiz sonuçlarına göre belirlenen kış gözü ortalama LTE 10 -50-90 sıcaklık değerlerinin dönemlere göre $p \leq$ 0.01 seviyesinde önemli olduğunu belirlemek için çoklu karşılaştırma testlerinden LSMeans Student ttesti yapılmış ve farklı gruplar farklı harflerle gösterilmiştir. 
Çizelge 1. Karaerik üzüm çeşidinin kış gözleri için TA ve DTA yöntemleri kullanılarak belirlenen mLTE ${ }_{10-50-90}$ değerlerinin değişimi.

\section{Örnekleme Dönemleri}

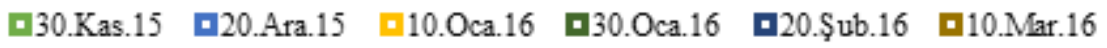
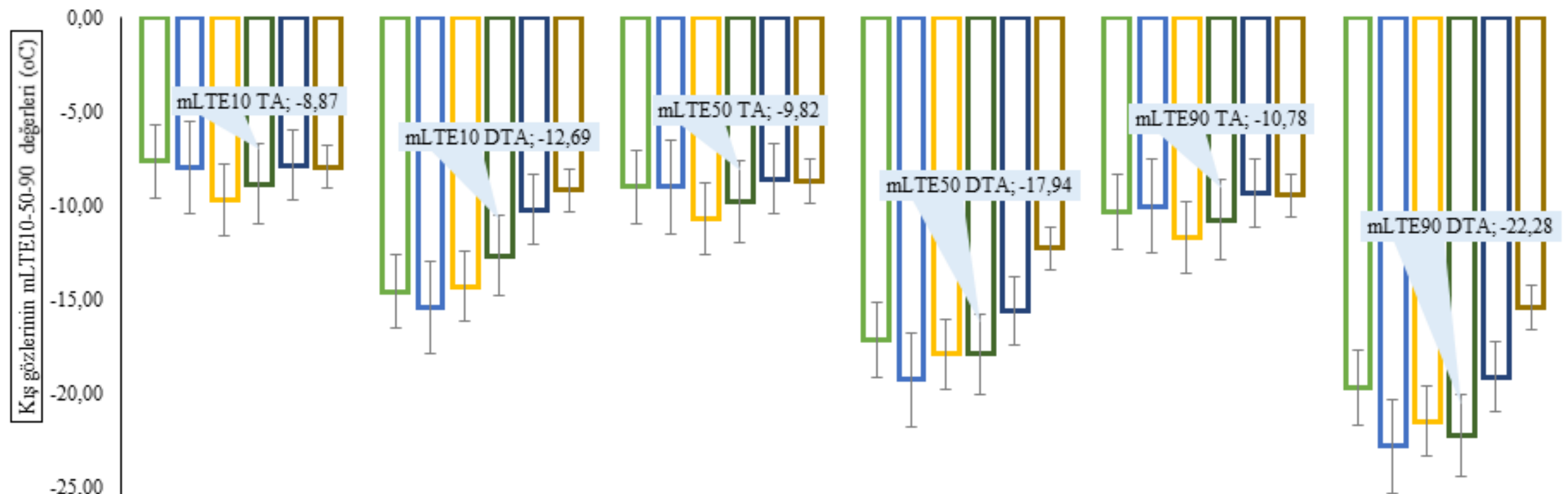

TA ve DTA yöntemlerine göre kış gözlerine ait ortalama düşük sıcaklik exoterm sıcaklikları (mLTE10-50-90)

\begin{tabular}{|c|c|c|c|c|c|c|}
\hline \multirow{2}{*}{$-30,00$} & \multirow{2}{*}{\multicolumn{2}{|c|}{ DTA }} & & & & \\
\hline & & & $\mathrm{TA}$ & DTA & TA & DTA \\
\hline 30.Kas.15 & $-7,66 \mathbf{b}$ & $-14,58 \mathbf{b c}$ & $-9,01$ bc & $-17,18 \mathbf{b}$ & $-10,36 \mathbf{b c}$ & $-19,73 \mathbf{c}$ \\
\hline 20.Ara.15 & $-8,00 \mathbf{a}$ & $-15,43 \mathbf{c}$ & $-9,02$ bc & $-19,30 \mathbf{a}$ & $-10,04 \mathbf{b c}$ & $-22,84 \mathbf{a}$ \\
\hline $10.0 \mathrm{ca} .16$ & $-9,70 \mathbf{a b}$ & $-14,33 \mathbf{b c}$ & $-10,71 \mathbf{a}$ & $-17,92 \mathbf{b}$ & $-11,72 \mathbf{a}$ & $-21,52 \mathbf{a}$ \\
\hline $30.0 \mathrm{ca} .16$ & $-8,87 \mathbf{a}$ & $-12,69 \mathbf{b}$ & $-9,82 \mathbf{a b}$ & $-17,94 \mathbf{b}$ & $-10,78 \mathbf{a b}$ & $-22,28 \mathbf{a}$ \\
\hline 20.Şub.16 & $-7,86 \mathbf{a b}$ & $-10,23 \mathbf{d}$ & $-8,60 \mathbf{c}$ & $-15,63 \mathbf{c}$ & $-9,34 \mathbf{c}$ & $-19,16 \mathbf{c}$ \\
\hline 10.Mar.16 & $-7,96 \mathbf{a b}$ & $-9,20 \mathbf{d}$ & $-8,71 \mathbf{b c}$ & $-12,30 \mathbf{d}$ & $-9,46 \mathbf{c}$ & $-15,43 \mathbf{d}$ \\
\hline
\end{tabular}

* Bir sütun içinde aynı harflerin bulunduğu gruplar arasındaki farklılıklar $p \leq 0.01$ seviyesinde önemli olduğu tespit edilmiştir. 


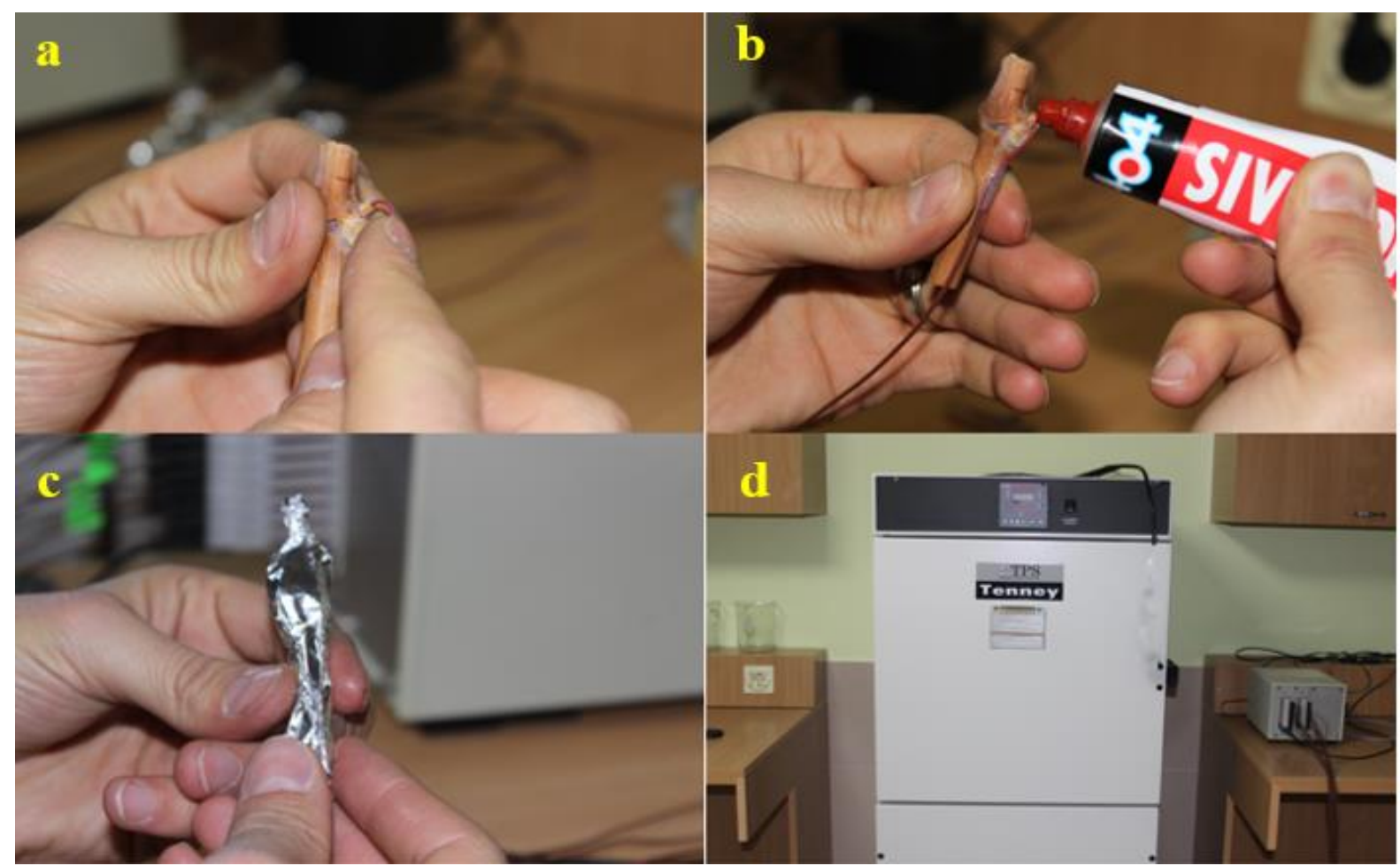

Şekil 1. TA yönteminin ile kış gözlerinde mLTE değerlerinin belirlenmesi; a. termokopulun primer tomurcuğa yerleştirilmesi, b. slikon ile tomurcuğun kapatılması, c. aleminyum folyo ile tomurcuğun sarılması, d. sıcaklık kontrollü kabine konulan tomurcuklarda veri kayıtlarının alınması

\section{Araştırma Bulguları ve Tartışma}

TA yöntemi sonuçları incelendiğinde, kış gözlerinde \%10 ölüm oranının ekzoterm sıcaklığını temsil eden $\mathrm{mLTE}_{10}$ değeri genel olarak kasım ayı dışında tüm dönemlerde aynı grup içerisinde yer almıştır. Bitkide yaprak döküm tarihine denk gelen bu ay içerisinde aklimasyon dönemi nedeniyle kış soğuklarına tam olarak aklime olamayan gözlerde $7,66^{\circ} \mathrm{C}^{\prime}$ lik bir ekzoterm sıcaklığı ile kendini göstermiştir. Kış gözlerinde $\mathrm{mLTE}_{50}$ değeri incelendiğinde ise aklimasyonun başlangıcı ile ekzoterm sıcaklıklarında düşmeler kademeli olarak meydana gelmiş, derin dinlenmenin tetiklendiği ocak ayı içerisinde en yüksek seviyeye ulaşmış ve ısınan hava sıcaklıklarının neden olduğu şubat mart dönemlerinde tekrardan yükselişe geçmiştir. İstatistik yönüyle Kasım, Aralık ve Mart aylarında $\mathrm{mLTE}_{50}$ değerleri arasında fark oluşmazken en düşük $\mathrm{mLTE}_{50}$ değeri $-10.71^{\circ} \mathrm{C}$ ile derin dinlenme dönemine denk gelen 10 Ocak dönemi içerisinde meydana gelmiştir. Kış gözlerinin \%90 ölüm sıcaklığı incelendiğinde $\mathrm{mLTE}_{50}$ değerlerinin belirlendiği ekzoterm sıcaklık değerleri gibi kış gözlerinin derin dinlenmede olduğu dönem içerisinde en fazla tolerans göstermiş ve $\mathrm{mLTE}_{90}$ değeri 10 Ocak örnekleme tarihinde $-11.72^{\circ} \mathrm{C}^{\prime}$ de gözlenmiştir (Çizelge 1).
DTA yöntemi sonuçları incelendiğinde, kış gözlerinde \%10 ölüm oranının ekzoterm sıcaklığını temsil eden $\mathrm{mLTE}_{10}$ değerleri kasım ve ocak döneminde sırasıyla $-14.58,-14.33$ ve $-12.29^{\circ} \mathrm{C}$ sıcaklıklarda görülmüştür. Örneklerde $\mathrm{mLTE}_{50}$ değeri $-19.30^{\circ} \mathrm{C}$ ile en düşük 20 Aralık döneminde, $\mathrm{mLTE}_{90}$ değerleri ise $-22.84,-21.52$ ve $-22.28^{\circ} \mathrm{C}^{\prime}$ lerin belirlendiği aralık ve ocak örnekleme dönemlerinde tespit edilmiştir. Genel olarak hem TA hem de DTA yöntemlerine göre teste tabi tutulan örneklere ait kış gözlerinin tüm dönemler göre $\mathrm{mLTE}_{10-50-90}$ sıcaklık değerlerinin değişimi sonbaharda dinlenmenin başlamasıyla beraber kademeli olarak artış göstermiş ve en düşük değere kış ortasında ulaşmıştır. Ardından ısınan havaların etkisi ile şubatmart aylarında stabil bir yapı izlemiştir. Ayrıca havaların ısındığı şubat-mart ayları her iki yöntem sonuçlarına göre en yüksek $\mathrm{mLTE}_{10,50,90}$ değerlerinin elde edildiği dönemler olarak belirlenmiştir (Çizelge 1). Nitekim mevsimsel olarak günlerin kısalması ve sıcaklıkların azalması aklimasyon süreci ile dokularda suyun azalmasını tetiklediğinden dokularda osmotik olarak aktif olmayan karbonhidratların birikimini teşvik etmektedir (Grant, 2012). Zira Kaya (2011), TA yöntemini kullanarak Karaerik üzüm çeşidinin kış gözlerinin don toleransının kasım sonu, aralık ve ocak aylarında maksimum seviyede olduğunu 
belirlemiştir. Benzer bir şekilde Buztepe (2016), TA yöntemini kullanarak aynı çeşide ait kış gözlerinin maksimum tolerans derecelerinin kasım sonu ve şubat ayının ilk haftasına kadar olan dönemler içerisinde meydana geldiğini bildirmiştir. Ayrıca çalışma sonuçlarımızı destekler nitelikte olan araştırmacılar kış gözlerinin $\mathrm{mLTE}_{50}$ değerlerinin dönemlere bağlı olarak $-4.65^{\circ} \mathrm{C},-13.63^{\circ} \mathrm{C}$ ile $-9.6^{\circ} \mathrm{C}$, $-12.7^{\circ} \mathrm{C}$ arasındaki ekzoterm sıcaklıklarında meydana geldiğini belirlemişlerdir (Buztepe, 2016; Kaya, 2011). Diğer yandan Grant (2012), asma gözlerinde düşük sıcaklığa toleransın ocak ayında maksimum olduğu ve $\mathrm{mLTE}_{50}$ değerlerinin daha düşük sıcaklıklarda ortaya çıktığını, bunun yanında mart ve nisan aylarında asma gözlerinin düşük sıcaklığa toleransının ise azaldığını tespit etmiştir. Ayrıca Concord çeşidinde sürgünün bazalındaki kış gözlerinin don toleransının ağustos ayından kasım ayına doğru giderek arttığı belirlenmiş ve bunun nedeni olarak dinlenme ve deaklimasyon dönemleri içerisinde kış gözlerindeki su içeriğindeki değişim gösterilmiştir (Fennell, 2004; Grant ve Dami 2015). Zira bitkinin dinlenmeye girişi ile dokulardaki su içeriğinde azalmanın olduğu bilinmekte (Kaya, 2011) ve mevcut çalışmamızda kış gözlerinde dönemlere bağlı olarak su içeriğinde meydana gelen değişmelerin tomurcukların ekzoterm sıcaklıkları üzerine farklı etki etmiş olabileceği düşünülmektedir. Öte yandan Mills ve ark, (2006) tarafından yapılan bir araştırmada, farklı üzüm çeşitlerinin derin dinlenmede olduğu dönemde DTA yöntemi ile analizleri yapılan tomurcuk mLTE $_{10,50,90}$ değerlerinin sırasıyla $-18,-21$ ve $-23^{\circ} \mathrm{C}$ sıcaklıklarda meydana geldiği bulunmuştur. Bu durum DTA yöntemini kullanılarak yürüttüğümüz çalışmamızda sırasıyla $-15.43,-19.30$ ve $-22.84^{\circ} \mathrm{C}^{\prime}$ de tespit edilen tomurcuk $\mathrm{mLTE}_{10,50,90}$ değerleri ile benzerlik göstermektedir.

Bulgularımızda, kış gözlerinden elde edilen mLTE 10 sıcaklık değerleri, TA yöntemi kullanıldığında -7.66 ile $-9.70^{\circ} \mathrm{C}$, DTA yöntemi kullanıldığında ise 9.20 ile $-15.43^{\circ} \mathrm{C}$ arasında tespit edilmiştir. TA yöntemi ile belirlenen $\mathrm{mLTE}_{50}$ sıcaklık değerleri incelendiğinde -8.60 ile -10.71 , DTA yöntemi ile belirlenen $\mathrm{mLTE}_{50}$ sıcaklık değerleri incelendiğinde ise -12.30 ile $-19.30^{\circ} \mathrm{C}$ arasında belirlenmiştir. Tomurcuk ölümlerinin \%90'nını temsil eden mLTE 90 değerleri TA yönteminde -9.34 ile -11.72 , DTA yönteminde -15.43 ile $-22.84^{\circ} \mathrm{C}$ arasında meydana gelmiştir. Araştırmada kış gözleri için belirlenen

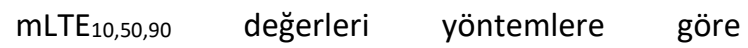
karşılaştırıldığında, dönemlere göre değişmekle beraber, DTA yöntemi TA yöntemi sonuçlarından sırasıyla 1.24 ile $7.43,3.59$ ile 10.28 ve 5.97 ile 12.80 ${ }^{\circ} \mathrm{C}$ daha düşük sıcaklıklarda meydana gelmiştir. Bu durumun temel nedeni, TA yönteminde termokuplların tomurcuğa yerleştirilirken dokularda fiziksel yapıyı bozmasıdır. Zira, Quamme (1978) yaptığı çalışmada termokopulların dokuya yerleştirilirken dokunun fiziksel yapısını bozduğunu tespit etmiştir. Ayrıca Kaya (2011) kış gözlerinin derin dinlenmede olduğu ocak ayı içerisinde TA analiz yöntemi kullanarak mLTE50 değerlerini $12.7^{\circ} \mathrm{C}^{\prime} \mathrm{de}$, yine Kaya (2018) DTA yöntemini kullanarak aynı üzüm çeşidinin mLTE50 değerlerini ise $-18.9^{\circ} \mathrm{C}^{\prime} \mathrm{de}$ tespit etmiştir. Çalışmamızı destekleyen bu bilgiler ışığında iki test metodu sonuçlarına bakıldığında, DTA yöntemi ile belirlenen $\mathrm{mLTE}_{50}$ değerleri TA yöntemi ile belirlenen $\mathrm{mLTE}_{50}$ değerlerinden $6.2^{\circ} \mathrm{C}$ daha yüksek sıcaklıklarda meydana geldiği görülmüştür.

\section{Sonuç ve Öneriler}

Bu çalışmada ilk kez TA ve DTA yöntemi birlikte kullanılmış ve yöntemlere göre belirlenen asma kış gözü düşük sıcaklık ekzotermleri sonuçları karşılaştırılmıştır. Asmanın maksimum soğuğa tolerans gösterdiği derin dinlenme döneminde DTA yöntemi ile belirlenen kış gözü mLTE 50 değerleri TA yöntemi sonuçları ile karşılaştırıldığında $10.28^{\circ} \mathrm{C}$ daha yüksek sıcaklıklarda meydana gelmiştir. Sonuçlarımız arasında farklılığa neden olan bu durumun TA yönteminde kış gözü içerisine yerleştirilen termokoplların tomurcuk yatağında oluşturduğu deformasyondan kaynaklandığı düşünülmektedir. $\mathrm{Bu}$ nedenle sonraki araştırmalarda farklı asma çeşit ve türlerine ait kış gözlerinin don toleransı tahminlerinde DTA yönteminin kullanılması ile daha gerçekçi verilerin elde edilebileceği kanaatine varılmıştır. Ancak farklı üzüm çeşit ve türlerinin düşük sıcaklık tolerans değerlendirilmesinde DTA yönteminin yapılamadı̆̆ı durumlarda TA yöntemi kullanılarak bu bireylerin genetik tabanında bulunan tolerans dereceleri arasındaki fark belirlenebilir. Ayrıca farklı uygulamaların çeşit ve türler için don toleransı üzerine olan etkisinin belirlenmesi çalışmalarda da TA yönteminden yararlanılabilir.

\section{Kaynaklar}

Andrews, P.K Sandidge, C.R III Toyama, T.K. 1984. Deep supercooling of dormant and deacclimating Vitis buds. American Journal of Enology and Viticulture, 35: 175-177.

Buztepe, A. 2016. Üzümlü İlçesi (Erzincan) Koşullarında Yetiştirilen Karaerik Üzüm Çeşidinde Pozisyonlarına Bağlı Olarak Kış Gözlerinin Dona Toleranslarının Belirlenmesi Yüksek Lisans Tezi. Atatürk Üniversitesi, Fen Bilimleri Enstitüsü, Erzurum.

Buztepe, A. Kose, C. Kaya, O. 2017. Evaluation of cold tolerance of dormant buds according to position using thermal analysis in karaerik ( $V$. 
vinifera L.) grape. International Journal of Research and Review, 4(10): 38-45.

Fennell, A. 2004. Freezing tolerance and injury in grapevines. Journal of Crop Improvement, 10(1-2): 201-235.

George, M.F. Becwar, M.R. Burke, M.J. 1982. Freezing avoidance by deep undercooling of tissue water in winter-hardy plants. Cryobiology, 19(6): 628-639.

Grant, T.N., Dami, I.E. 2015. Physiological and biochemical seasonal changes in Vitis Genotypes with contrasting freezing tolerance. American Journal of Enology and Viticulture. 66(2): 195-203.

Grant, T.N.L. 2012. Characterization of Cold and Short Day Acclimation in Grape Genotypes of Contrasting Freezing Tolerance. The Ohio State University. Doctoral Dissertation.

Kalkan, N.N. Kaya, Ö. Karadoğan, B. Köse, C. 2017. Farklı gövde yüksekliğine sahip karaerik (Vitis vinifera L.) Üzüm çeşidinin kış gözlerinde soğuk zararı ve lipid peroksidasyon düzeyinin belirlenmesi. Alınteri Zirai Bilimler Dergisi, 32(1):11-17.

Kaya, Ö. 2011. Üzümlü İlçesi (Erzincan) Koşullarında Yetiştirilen Karaerik Üzüm Çeşidinde Koltuk Sürgünü Varlığının Kış Gözlerinin Dona Dayanımı Üzerindeki Etkilerinin Belirlenmesi. Yüksek Lisans Tezi. Atatürk Üniversitesi, Fen Bilimleri Enstitüsü, Erzurum.

Kaya, Ö., Köse, C. 2017. Determination of resistance to low temperatures of winter buds on lateral shoot present in Karaerik (Vitis vinifera L.) grape cultivar. Acta Physiologiae Plantarum, 39(9): 201-209.

Kaya, Ö. Köse, C. 2018. Düşük sıcaklık zararının asma üzerindeki etkileri. Yüzüncü Yıl Üniversitesi Tarım Bilimleri Dergisi, 28(2): 241-253.

Kaya, O. Kose, C. Gecim, T. 2018. An exothermic process involved in the late spring frost injury to flower buds of some apricot cultivars (Prunus armenica L.). Scientia Horticulturae, 241: 322-328.

Keller, M., 2015. The Science of GrapevinesAnatomy and Physiology. Burlington, MA: Academic Press.

Köse, C., Güleryüz, M. 2009. Üzümlü ilçesi (Erzincan) karaerik üzüm bağlarında 2007-2008 kış soğuklarının kış gözlerinde yol açtığı zararlar. Atatürk Üniversitesi, Ziraat Fakültesi Dergisi, 40(1): 55-60.

Köse, C., Kaya, Ö. 2017. Determination of resistance to low temperatures of winter buds according to position in karaerik ( $V$. vinifera L.) grape cultivar. International Journal of Scientific and Research Publications, 7(4): 45.
Mills, L.J. Ferguson, J.C. Keller, M. 2006. Coldhardiness evaluation of grapevine buds and cane tissues. American Journal of Enology and Viticulture, 57: 194-200.

Pierquet, P. Stushnoff, C., Burke, M.J. 1977. Low temperature exotherms in stem and bud tissues of Vitis riparia Michx. Journal of the American Society for Horticultural Science, 102: 54-55.

Proebsting, Jr, E.L. Sakai, A. 1979. Determining T50 of Peach Flower Buds with Exotherm Analysis [Cold Injury, Resistance]. HortScience (USA).

Quamme, H.A. 1978. Mechanism of supercooling in overwintering peach flower buds. Journal of the American Society for Horticultural Science, 103: 57-61.

Quamme, H.A., R.E.C. Layne, H.O. Jackson, G.A. Spearman. 1975. An improved exotherm method for measuring cold hardiness of peach flower buds. HortScience 10: 521-523.

Rende, M. Kose, C. Kaya, O. 2018. An assessment of the relation between cold-hardiness and biochemical contents of winter buds of grapevine cv.'Karaerik'in acclimationhardening-deacclimation

phases. Mitteilungen Klosterneuburg, Rebe und Wein, Obstbau und Früchteverwertung, 68(2): 67-81.

Zhang, J., Wu, X., Niu, R., Liu, Y., Liu, N., Xu, W., Wang, Y. 2012. Cold resistance evaluation in 25 wild grape species. Vitis, 51: 153-160. 